DOI 10.4467/2543733XSSB.17.002.9977

JAN RYCHLÍK

Uniwersytet Karola w Pradze

\title{
PAŃSTWO CZESKIE PODCZAS WOJNY TRZYDZIESTOLETNIEJ ${ }^{1}$
}

\author{
The Bohemian State During the Thirty Years War
}

Summary

The article describes the uprising of the Bohemian Protestant Estates (1618-1620) against the Habsburg Emperor Ferdinand II. and the political developments in Bohemian lands up to the end of Thirty Years War in 1648. The aim of the article is to show the transformation of the Bohemian state from an estate monarchy into an absolute monarchy ruled by the Emperor-King. This process was possible due to the victory of Ferdinand II. over the rebellious Bohemian Protestant estates in the Battle at the White Mountain at the outskirts of Prague on 8 November 1620. After the suppression of the uprising the participants were severely punished, their property confiscated and the political significance of the estates severely curtailed. The victory of the army of Ferdinand II also meant a victory of Catholicism. Protestant nobles and burgers had to convert to Catholicism or to leave the country. In the classical Czech historical discourse the battle at the White Mountain is considered to be the end of the Bohemian independence. The article shows that in reality it was not exactly so: the royal absolutism imposed by Ferdinand II after White Mountain completely changed the political nature of the Lands of the Bohemian Crown, but, on the other hand, the Habsburgs still ruled the country only as the kings of Bohemia, just like before 1618, e.g. before the estate uprising.

Keywords: Thirty Years War, Bohemian State, The Rising of Bohemian Estates

Słowa kluczowe: wojna trzydziestoletnia, państwo czeskie, powstanie Stanów Czeskich

\footnotetext{
${ }^{1}$ Prezentowany artykuł jest fragmentem przygotowanej monografii pt. Historia Czech, która jest pierwszą nowoczesną syntezą czeskiej historii w języku polskim. Tekst jest przepracowaną wersją z wydania czeskiego (nazwa czeskiego oryginału: J. Rychlík-V. Penčev, Od minulosti k dnešku. Dějiny českých zemí, Praha 2013).
} 


\section{Czeskie powstanie stanowe 1618-1620}

Od początku XVII w. środkowa i zachodnia Europa była już ostatecznie podzielona na obóz katolicki i protestancki. Wkrótce podział ten miał stać się tłem pierwszego wielkiego konfliktu ogólnoeuropejskiego, zwanego wojną trzydziestoletnią (1618-1648). Chociaż na zewnątrz, zwłaszcza w pierwszej fazie wojny, wydawało się, że ma charakter religijny, w istocie wynikał głównie z przyczyn politycznych, związanych z walką o hegemonię na kontynencie. Przeciwko potędze Habsburgów, rządzących w Europie Środkowej i Hiszpanii, zaczęły tworzyć się z czasem różnego rodzaju koalicje. Ziemie czeskie, wówczas w większości protestanckie, lecz rządzone od prawie stu lat przez katolickich Habsburgów, siłą rzeczy musiały stać się jednym z centrów zbliżającego się konfliktu. W warunkach czeskich był on jeszcze dodatkowo związany z walką o charakter państwa. Chodziło o to, czy zachowa ono kształt monarchii stanowej, czy też ulegnie królewskiemu absolutyzmowi na wzór Hiszpanii i Francji. W ówczesnych czasach absolutyzm wiązał się z szansą modernizacji państwa, w tym budowy jego nowoczesnych struktur. W warunkach monarchii habsburskiej, która od roku 1526 była unią personalną Austrii, Czech i Węgier², oznaczał jednak likwidację suwerenności jej poszczególnych części, a więc także ziem tworzących Królestwo Czeskie.

Bezpośrednią przyczyną wojny stał się spór o protestanckie kościoły w Broumovie w północno-wschodnich Czechach i Hrobach w Rudawach ${ }^{3}$. Listem majestatycznym Rudolfa II (1576-1611) z 9 lipca 1609 r. gwarantowano wszystkim obywatelom Czech pełną wolność religijną. Dodatek do dokumentu, zastępujący pokój religijny z 1485 r., ustanawiał zasadę, zgodnie z którą każdy pan mógł w swym majątku stawiać kościół i szkoły oraz sprowadzać duchownych i nauczycieli według swojej wiary, nie mógł jednak zmuszać do jej wyznawania swoich poddanych. Prawo fundowania kościołów zgodnie z własną wiarą mieli jednak tylko wolni obywatele, tj. arystokracja, szlachta i mieszczaństwo wolnych miast królewskich, a spośród ludności poddanej jedynie ci, którzy mieszkali na królewszczyźnie. Miasta Broumov i Hroby były prywatne, Broumov należał do dóbr miejscowego klasztoru, a Hroby do arcybiskupstwa praskiego, zaś kościoły, o które wybuchł spór, zostały ufundowane przez miejscowych ewangelików. Protestanci argumentowali, że majątek kościelny był pierwotnie własnością królewską, która niejako została Kościołowi wydzierżawiona, jednak katolicy odrzucali tę argumentację. Za zgodą namiestników królewskich oba kościoły zamknięto, a ten w Hrobach na rozkaz arcybiskupa Pragi zburzono. W obronie miejscowych ewangelików wystąpiła szlachta protestancka i miasta królewskie, zwołując, mimo zakazu cesarza Macieja II (1611-1619), zjazd w Pradze. Po burzliwym spotkaniu w auli Uniwersytetu Karola 23 maja 1618 r. prawie trzystu przedstawicieli szlachty protestanckiej ruszyło na zamek. Tam wtargnęli do pomieszczeń kancelarii czeskiej,

\footnotetext{
${ }^{2}$ Bezdzietna śmierć Ludwika Jagiellończyka pod Mohaczem w 1526 r. oznaczała konieczność wyboru zarówno nowego władcy Czech, jak i Węgier wraz z Chorwacją. O wszystkie te trony zamierzał walczyć książę Ferdynand I Habsburg, którego żoną była siostra Ludwika. Dnia 23 października 1526 r. Ferdynand Habsburg został jednogłośnie wybrany na króla Czech. Ferdynand Habsburg, który już w 1531 r. został królem Niemiec, otrzymał w 1556 r. koronę cesarską. Od tego czasu wszyscy kolejni Habsburgowie na tronie czeskim (Maksymilian II, Rudolf II i jego brat Maciej II) używali tytułu cesarskiego, jednak w Czechach dalej rządzili wyłącznie z tytułem królów czeskich.

${ }^{3}$ J. Kilián, 11. 12. 1617 - Uzavřeni kostela v Hrobu. Na cestě k defenestraci, Praha 2007.
} 
oskarżając obecnych urzędników królewskich o łamanie wolności religijnej. Po pełnej emocji dyskusji wzburzeni protestanci uwięzili kilku urzędników, zaś dwóch namiestników cesarskich: Wilhelma Slavatę z Chlumu i Jarosława Bořitę z Martinic wraz z ich pisarzem Filipem Fabriciem wyrzucili przez okno. Chociaż spadli z ponad dziesięciu metrów, szczęśliwie uszli z życiem. Przez krótki czas ukrywali się w pałacu katolickiej szlachcianki Polyxeny z Lobkovic, po czym zdołali zbiec do Wiednia, gdzie poinformowali o całym zdarzeniu cesarza.

Defenestracja praska dała początek powstaniu stanów czeskich. Co prawda cesarzowi Maciejowi oznajmiono, że nie jest ono skierowane przeciwko niemu i nadal uznawany jest za prawowitego władcę Czech, to w istocie sytuacja wyglądała inaczej. Powstańcy powołali rząd złożony z trzydziestu dyrektorów, po dziesięciu z arystokracji, szlachty i mieszczaństwa, który miał administrować państwem oraz zaczęli mobilizować armię. Dla zdobycia odpowiednich środków wygnano z Czech jezuitów i przejęto ich majątek, a także ustanowiono specjalny podatek. Rząd wysłał posłów do sąsiednich państw z prośbą o udzielenie pomocy. Przeciwko cesarzowi powstały Śląsk i Łużyce, pewnego wsparcia czeskim stanom udzielili ewangelicy z Dolnej i Górnej Austrii. Inaczej rzecz się miała z Morawami. Sejm ziemski, zwołany do Brna 25 czerwca 1618 r., przyją, na wniosek Karola starszego z Žerotína, stanowisko odrzucające współpracę z powstańcami.

Reakcja w Wiedniu była początkowo dość niepewna; główny doradca i powiernik cesarza, kardynał Melchior Khlesl, otrzymał zadanie, by negocjować z czeskimi stanami. Jednak nastroje bojowe wzięły górę. Khlesl został 20 lipca uwięziony, a następnie internowany w Tyrolu. Na początku sierpnia armia cesarska, na której czele stanął francuski generał Henry Duval Dampierre, przekroczyła granice Czech, próbując bez skutku zdobyć Jindřichův Hradec, zaś później skierowała się na północ. Pod koniec sierpnia na Morawy wkroczyła z kolei armia pod dowództwem generała Karola Bonawentury Longuevala, hrabiego Bucquoy. Wojska cesarskie połączyły się pod Č́slaviem, tam jednak zostały powstrzymane przez armię stanów i zmuszone do wycofania się w kierunku Czeskich Budziejowic. Ten sukces stanów czeskich odbił się głośnym echem na Śląsku, który pod jego wpływem 12 września postanowił przyłączyć się do powstania. 9 listopada dowódca wojsk powstańczych Henryk Maciej z Thurnu pobił armię Bucquoya między Veselím a Lomnicą, a wkrótce kolejną porażkę odniosły oddziały generała Dampierre’a, pokonane pod Novymi Hradami. Niesieni falą zwycięstw powstańcy dotarli aż pod Wiedeń. W dniu 21 listopada wojska Arnoszta z Mansfeldu, opłacane przez sprzyjającego stanom czeskim księcia sabaudzkiego, zajęły wierne dotąd cesarzowi katolickie Pilzno.

Gdy 20 marca 1619 r. zmarł nagle cesarz Maciej II, jego bratanek Ferdynand, zagorzały katolik, którego czeski Sejm już 5 czerwca 1617 r. uznał za przyszłego „wybranego, uznanego i dziedzicznego" króla ${ }^{4}$, oznajmił czeskim stanom, że przejmuje władzę w kraju. Jednak czescy protestanci stanęli otwarcie przeciwko władcy, którego trzy lata wcześniej przyjęli za swego króla, argumentując, że nigdy nie doszło do formalnej elekcji, w dodatku zatwierdzenie jego kandydatury w 1617 r. odbyło się pod przymusem. Taką postawę stanów czeskich Ferdynand musiał odebrać jako osobistą zniewagę i zdradę stanu. Nie było już

\footnotetext{
${ }^{4} \mathrm{Z}$ ówczesnego punktu widzenia nie było różnicy (jeśli chodzi o skutki prawne) między uznaniem za króla a elekcją króla, która w istocie po raz ostatni przeprowadzona została w 1526 r. Ferdynand był także królem „dziedzicznym”, ponieważ bezdzietny cesarz Maciej adoptował go.
} 
szans na kompromis i jedynym rozwiązaniem stała się próba sił. Sytuacja militarna wydawała się korzystna dla czeskich stanów. Sprzeciw protestantów wobec Habsburgów rozgorzał także w Górnej Austrii, wzniecony przez kalwina Georga Erasmusa Tschernembla, zwolennika konfederacji ze stanami czeskimi, dla której pozyskał poparcie również dolnoaustriackich ewangelików ${ }^{5}$. W kwietniu powstanie objęło nadto Łużyce, a wreszcie i Morawy, co stało się pod naporem wojsk stanów czeskich, które wkroczywszy na tereny Moraw, 2 maja 1619 r. dokonały przewrotu w Brnie. Władzę w mieście przejęli protestanci pod wodzą Ladislava Velena z Žerotína, który dwa dni później objął też urząd hetmana ziemskiego, gdy sejm morawski usunął z tego stanowiska katolika Ladislava z Lobkovic. Poza tym powołano morawski dyrektoriat (składający się z 12 arystokratów, 12 szlachciców i 6 mieszczan), który ogłosił przystąpienie Moraw do konfederacji stanów czeskich, śląskich i górnołużyckich, a tym samym do powstania przeciwko Habsburgom. Morawscy i śląscy żołnierze zaczęli zaciągać się do armii powstańczej, która tymczasem znów ruszyła na Wiedeń. Henryk Maciej z Thurnu liczył na pomoc wiedeńskich ewangelików. Ci 5 czerwca wymusili na Ferdynandzie przyjęcie ich na audiencji w Hofburgu, podczas której zażądali potwierdzenia swoich praw. Niemniej Ferdynand odmówił, tym samym sporo ryzykując, znalazł się bowiem sam na sam z uzbrojonymi protestantami, którzy bez trudu mogli go uwięzić. W tym krytycznym momencie na pomoc Ferdynandowi przybyły cztery kompanie kirasjerów Dampierre’a. Dzień później pod mury Wiednia dotarła armia powstańcza, było już jednak za późno, ponieważ wraz z przybyciem kirasjerów sytuacja w Wiedniu przechyliła się na korzyść katolików. Miejscowi ewangelicy stawili się co prawda w obozie Henryka Macieja, obiecując mu pomoc wojskową, jednak o otwarciu bram miasta nie chcieli słyszeć. Powstańcy nie mieli szans na skuteczne oblężenie miasta, głównie z powodu słabej artylerii, obawiali się także nadejścia kolejnych posiłków ${ }^{6}$. Co więcej, 10 czerwca armia Arnoszta z Mansfeldu, zajmująca Pilzno, została pobita przez wojska Bucquoya pod Záblatem, niedaleko Vodňan. W tej sytuacji Henryk Maciej dał rozkaz odwrotu do Czech.

W lecie 1619 r. doszło do znaczącego wzmocnienia powstania pod względem politycznym. Dnia 8 lipca w Pradze zwołano sejm generalny ${ }^{7}$, który 31 lipca przyjął nową konstytucję, wzorowaną na ustroju Republiki Zjednoczonych Prowincji Niderlandów. Korona Czeska miała być w przyszłości konfederacją pięciu ziem z własnymi rządami, przy czym zwierzchnią władzę miał sprawować już nie król, lecz stany. W praktyce Królestwo Czech stawało się monarchią stanową, w której król jest jedynie tytularnym władcą, podobnie jak miało to miejsce w sąsiedniej Rzeczpospolitej szlacheckiej. Konstytucja, zwana artykułami konfederackimi (było ich w sumie sto), opisywała stosunki między poszczególnymi ziemiami i sposoby rozwiązywania wspólnych kwestii, gwarantowała ochronę religii ewangelickiej i stanów oraz wspólną obronę $e^{8}$ W sprawach religijnych nadal obowiązywał list majestatyczny Rudolfa, zapewniający wolność wyznania także katolikom. Faktycznie nie dochodziło wówczas do prześladowań katolików, na dodatek, niektórzy

\footnotetext{
${ }^{5}$ K. W. Schwarz, Der „politische” Kalvinist Georg Erasmus Tschernembl (1567-1626) und sein Kampf um die Religionsfreiheit in Oberösterreich, [w:] Historia Ecclesiastica, I, 2010, No 1-2, s. 91-92.

${ }^{6}$ M. Koldinská, Kryštof Harant z Polžic a Bezdružic, Praha-Litomyšl, 2004, s. 369-371.

${ }^{7}$ Sejmem generalnym nazywano wspólne obrady delegatów z wszystkich krajów Korony Świętego Wacława, tj. Czech, Moraw, Śląska i Łużyc.

${ }^{8}$ Tekst artykułów konfederackich patrz: Z. Veselý, Déjiny českého státu v dokumentech, Praha 2003, s. $152-170$.
} 
z nich angażowali się po stronie powstańców (tak było m.in. z Divišem Černínem z Chudenic, który w 1621 r. został za to stracony). W istocie nowe państwo miało jednak wyraźnie protestancki charakter.

W dniu 16 sierpnia do konfederacji dołączyli ewangelicy z Dolnej i Górnej Austrii, a dwa dni później sejm generalny zdecydował o detronizacji Ferdynanda II jako króla Czech. O wolny tron zabiegał elektor saski Jan Jerzy, niemniej stany czeskie, po pewnym wahaniu, oddały go 26 sierpnia 1619 r. elektorowi Palatynatu, Fryderykowi V Wittelsbachowi, przywódcy unii protestanckich książąt niemieckich i zięciowi króla Anglii, Jakuba I. Co ciekawe, dwa dni później we Frankfurcie nad Menem Ferdynand II został wybrany na cesarza, także głosem Fryderyka V.

Wittelsbach przybył do Czech 1 listopada 1619 r., witany uroczyście jako nowy król przed bramami Pragi w zameczku Hvězda na Białej Górze. Jeszcze przed koronacją musiał złożyć przysięgę na artykuły konfederackie, zapewniające władzę sejmom poszczególnych ziem, bez których zgody nie mógł w istocie niczego uczynić. Uroczysta koronacja odbyła się w katedrze św. Wita na Hradczanach. Do historii przeszedł Fryderyk jako król zimowy, miało się bowiem okazać, że jego władza w Czechach przetrwała tylko jedną zimę?.

Wybierając Fryderyka na nowego króla, czeskie stany liczyły na wydatną pomoc międzynarodową, tak ze strony Anglii i protestanckich książąt niemieckich, jak i innych przeciwników Habsburgów, w tym Francji i Imperium Osmańskiego, a przynajmniej Siedmiogrodu. Nic takiego się jednak nie stało. Król Anglii Jakub I zabiegał właśnie o rękę infantki hiszpańskiej dla swego syna Karola i walka z Habsburgami nie leżała w jego interesie. Ponadto znajdował się wówczas w poważnym konflikcie z parlamentem i nie zamierzał wspierać buntowników, którzy obalili legalnego władcę, nawet jeśli zastąpili go jego własnym zięciem ${ }^{10}$. Także Francja, z powodu sytuacji wewnętrznej, nie mogła angażować się akurat w żaden konflikt. Pomocy odmówili i książęta niemieccy, a elektor saski Jan Jerzy, któremu nie udało się zdobyć korony czeskiej, przeszedł na stronę Ferdynanda w zamian za obietnicę oddania mu Łużyc. Ograniczoną pomoc finansową obiecały Czechom jedynie Zjednoczone Prowincje ${ }^{11}$ i Wenecja, a po stronie Fryderyka stanął również, za zgodą Wielkiej Porty, siedmiogrodzki książę Gábor Bethlen (1613-1629). Po śmierci Macieja pusty pozostał także tron Węgier, co stanowiło dla Bethlena nie lada pokusę. Tak jak niegdyś uczynił to Bocskay, tak teraz on ogłosił się obrońcą węgierskich protestantów i z cichą pomocą Turcji ruszył na pozycje Habsburgów, szybko opanowując węgierskie Zacisie i całą wschodnią Słowację. W 1620 r. protestanckie stany węgierskie wybrały go na króla.

\section{Bitwa pod Białą Górą i początki absolutyzmu}

Od II połowy 1619 r. fortuna zaczęła coraz bardziej sprzyjać cesarzowi. Dnia 8 października zawarto w Ulm tajne porozumienie między Ferdynandem II i przywódcą Ligii Katolickiej Maksymilianem Bawarskim. Już wcześniej swą pomoc obiecał cesarzowi król

\footnotetext{
${ }^{9}$ Biografię Fryderyka patrz: J. Čechura, Zimní král aneb české dobrodružství Fridricha Falckého, Praha 2004.

${ }^{10}$ J. Polišenský, Anglie a Bílá Hora 1618-1620, Praha 1949.

${ }^{11}$ J. Polišenský, Nizozemská politika a Bílá Hora, Praha 1958.
} 
Hiszpanii Filip III. Wsparcie nadeszło także z Polski, ze strony króla Zygmunta III Wazy, który był szwagrem Ferdynanda. Na początku 1620 r. Zygmunt wysłał mu na pomoc oddział lekkiej jazdy, zwany lisowczykami od swego pierwszego dowódcy, hetmana Aleksandra Lisowskiego, który złupił Morawy ${ }^{12}$. Nawet jak na ówczesne stosunki lisowczycy wykazywali się nie lada okrucieństwem. Dnia 3 lipca 1620 r. zawarto w Ulm między Unią Protestancką i Ligą Katolicką pakt o nieagresji, który umożliwił Maksymilianowi wzmocnienie swojej armii i przygotowanie wyprawy przeciwko powstaniu. 22 lipca jego armia wyruszyła na Linz, gdzie zmusiła stany dolnoaustriackie do kapitulacji. Górna Austria poddała się 8 września, a pięć dni później pod naporem wojsk elektora saskiego Jana Henryka padły Łużyce. Armia księcia Bucquoya połączyła się z wojskami Ligii Katolickiej generała Johanna Tilly’ego pod Oberndorfem i 16 września ruszyła na Czechy.

Od jesieni sytuacja Fryderyka nieustannie się pogarszała. Pod naporem Maksymiliana Bawarskiego wojska stanowe cofały się coraz mocniej z południa Czech w kierunku Pilzna, co otworzyło katolikom drogę ku Pradze. Jeszcze 5 listopada powstańcy próbowali zatrzymać armię Maksymiliana pod Rakovníkiem, jednak bez skutku. Pod zameczkiem Hvězda na Białej Górze, w tym samym miejscu, w którym rok wcześniej stany czeskie uroczyście witały nowego króla, doszło 8 listopada 1620 r. do decydującej bitwy, w istocie niewielkiego starcia, trwającego mniej niż dwie godziny. Źle opłacane wojsko stanowe, które już od trzech miesięcy nie otrzymywało żołdu, po krótkim ataku po prostu ustapiło pola. Fryderyk, gdy tylko doniesiono mu o wydarzeniach na Białej Górze, natychmiast opuścił zamek i schronił się na Starym Mieście, a dzień później uciekł z Pragi, przez Hradec Králové i Kłodzko na Śląsk, a stamtąd do Brandenburgii. Z militarnego punktu widzenia bitwa pod Białą Górą nie miała istotnego znaczenia, przeważająca część Czech i Moraw wciąż pozostawała pod kontrolą zbuntowanych stanów, co więcej, od wschodu podążała im na pomoc armia Gábora Bethlena. Także Praga mogła się jeszcze bronić. Jednak po ucieczce króla przywódcy powstania i prascy mieszczanie wpadli w panikę i zaoferowali Maksymilianowi kapitulację. Wielu powstańców wysłało do Ferdynanda pokorne listy, w których żałowali swego udziału w buncie i uznawali go za pełnoprawnego króla. Sam Ferdynand nie miał początkowo świadomości, jak wielki był rozmiar zwycięstwa. Gdy jednak w ślad za Pragą zaczęły bez walki kapitulować inne czeskie miasta i kolejne ziemie ${ }^{13}$, zdecydował się wymierzyć przykładną karę i czym prędzej przystąpić do rekatolizacji Czech i zaprowadzenia rządów absolutystycznych.

\footnotetext{
${ }^{12} \mathrm{Z}$ wyprawą lisowczyków na Morawy związana jest historia katolickiego księdza ze Skoczowa i proboszcza w Holešovie, Jana Sarkandra. Gdy lisowczycy dotarli 5 lutego 1620 r. pod Holešov, Sarkander na czele grupy katolików wyszedł im naprzeciw, niosąc monstrancję z Najświętszym Sakramentem i prosząc, by odjechali. Według tradycji katolickiej lisowczycy na widok Hostii zsiedli z koni, przeżegnali się, niektórzy nawet uklękli, i faktycznie odstapili. Miejscowi ewangelicy nabrali podejrzeń, że Sarkander był w zmowie z Polakami, a wszystko było tylko przedstawieniem. Przypomniano mu, że rok wcześniej przebywał w Polsce, gdzie zapewne uprosił samego Zygmunta III Wazę o przysłanie wojsk. W rzeczywistości wsparcie polskiej jazdy uzyskał generał Michał Althan, a Sarkander nigdy w Warszawie nie był. Na rozkaz stanów morawskich Sarkander został pojmany i wysłany do Ołomuńca, gdzie poddano go strasznym torturom. Jako że był on spowiednikiem Ladislava z Lobkovic, brata najwyższego kanclerza Zdenka Wojciecha Popela, niegdysiejszego hetmana ziemskiego, próbowano wydobyć od niego zeznania, że Ladislav był zaangażowany w katolicki spisek. Dnia 17 marca 1620 r. Sarkander zmarł w wyniku tortur. Kościół katolicki ogłosił go męczennikiem, który zginął w imię zachowania tajemnicy spowiedzi. Został beatyfikowany przez papieża Piusa IX w 1859 r. i kanonizowany przez Jana Pawła II w 1995 r. Patrz: J. Kadlec, Přehled českých církevních dějin, II, Řím (Roma)-Praha, 1987, s. 69-70.

${ }^{13} \mathrm{~W}$ dniu 13 grudnia 1620 r. skapitulowały Morawy, a wiosną 1621 r. Śląsk i Łużyce.
} 
Wiosną 1621 r. przywódcy powstania zostali uwięzieni i postawieni przed nadzwyczajnym trybunałem, któremu przewodniczył namiestnik cesarski, Karol z Lichtensteinu. Zapadły 43 wyroki śmierci, z których cesarz zatwierdził 27. Wykonano je rankiem 21 czerwca przed ratuszem Starego Miasta w Pradze. Wśród straconych znalazło się 3 arystokratów, 7 szlachciców i 17 mieszczan ${ }^{14}$. Egzekucji dokonano w niezwykle okrutny sposób. Większość skazanych ścięto, trzech mieszczan powieszono, a w wielu wypadkach odcinano skazanym ręce lub wyrywano język. Dwanaście ściętych głów wywieszono na wieży mostu Karola lub wysłano, dla przestrogi, do rodzinnych miast skazanych. Wiele osób skazano na więzienie, chłostę, konfiskatę ziemi. W pamięci narodu staromiejska egzekucja 27 czeskich panów zapisała się na trwałe, a skazani stali się w dobie odrodzenia narodowego kimś w rodzaju męczenników za czeską sprawę.

Na Morawach rozprawiono się z powstańcami w nieco bardziej łagodny sposób. Tamtejszy trybunał, pod przewodnictwem kardynała Franciszka Ditrichsteina, zabrał się do pracy dopiero wiosną 1622 r. Oprócz osądzenia osób już nieżyjących lub zbiegłych z kraju wydano co prawda 20 wyroków śmierci, jednak niemal we wszystkich przypadkach karę tę zamieniono na więzienie ${ }^{15}$.

W 1622 r. Ferdynand II udzielił generalnej amnestii uczestnikom powstania. Kary można było uniknąć tylko na ,gardle i czci”, ale już nie na majątku, i to pod warunkiem osobistego stawienia się w określonym terminie przed specjalną komisją i wyznania swoich win. Cesarz ostrzegał w swym manifeście, że każdy, kto nie zgłosi się dobrowolnie, a zostanie mu później udowodniony udział w powstaniu, zostanie stracony. Wszystko to było jedynie pretekstem do zasilenia skarbca cesarskiego na potrzeby prowadzonej wojny, która w latach 1621-1623 toczyła się głównie w Palatynacie, rodowych dobrach Zimowego Króla. Poszczególni szlachcice i mieszczanie, bojąc się o swoje życie, zgłaszali się pospiesznie przed komisje, przyznając się często do mało znaczących spraw, jak przyjęcie urzędu z rąk Fryderyka czy zaciągnięcie się do wojska. Komisja najczęściej wydawała postanowienie o ułaskawieniu i darowaniu życia, ale za cenę konfiskaty majątku w części lub w całości. Nawet przy częściowej konfiskacie ułaskawionemu zabierano cały majątek nieruchomy, za który miał otrzymywać potem proporcjonalne odszkodowanie, co jednak zdarzało się rzadko, bowiem skarb królewski świecił pustkami. Chcąc jak najszybciej sprzedać konfiskowane majątki, czyniono to nieraz znacznie poniżej ich wartości, albo oddawano je za darmo cesarskim protegowanym ${ }^{16}$.

Skutkiem konfiskat był upadek dużej części starej czeskiej szlachty, zwłaszcza niższej, i pojawienie się nowych rodów, przeważnie cudzoziemskich. Jak to bywa przy okazji tego

${ }^{14}$ Wśród straconych znaleźli się: Jan Jesenský (Jesenius), lekarz i rektor Uniwersytetu Karola, który przeprowadził niegdyś pierwszą publiczną sekcję zwłok, 86-letni Kašpar Kapliř z Sulevic, Joachim Ondřej Šlik, Wacław Budovec z Budova i Krzysztof Harant z Polžic. Jeden z członków dyrektoriatu, autor apologii powstania Martin Fruwein uniknął publicznej egzekucji, popełniając samobójstwo w celi. Jan Teodor Sixt z Ottersdorfu został ułaskawiony już na miejscu kaźni, jako jedyny ze skazanych. W gronie straconych znalazł się jeden katolik, Diviš Černín z Chudenic, którego brat, Herman Černín, był członkiem cesarskiego trybunału. Patrz: J. Petráň, Staroměstská exekuce, 4. wyd., Praha 2004.

${ }^{15}$ Wyrok wykonano jedynie na Wacławie Bítovskim z Bítova, ale dopiero osiem lat później. Pozostałym skazanym oszczędzono śmierci za wstawiennictwem samego kardynała Ditrichsteina oraz Karola starszego z Žerotína. Niewykluczone, że wpływ na tę decyzję miała nowa wyprawa Gábora Bethlena na Morawy i jednoczesny atak wojsk ewangelickiego księcia Karniowa, Jana Jerzego Hohenzollerna.

${ }^{16}$ T. V. Bílek, Dějiny konfiskaci v Čechách po roce 1618, I, Praha 1882; II, Praha 1883. 
rodzaju zmian majątkowych, istniała grupa ludzi, która znacząco się na nich wzbogaciła. Najbardziej znanym i najbardziej rażącym przykładem stał się drobny szlachcic i dowódca wojskowy, Albrecht z Valdšteinu (Wallenstein), protestant, który z koniunkturalnych powodów przeszedł na katolicyzm. W czasie powstania był jednym z dowódców wojsk stanowych, jednak przeszedł na stronę cesarza i stał się jednym z jego najzdolniejszych generałów. W czasie konfiskat majątków wzbogacił się tak bardzo, że mógł z własnych pieniędzy wystawić armię. Cesarz, który zaciągnął u niego dług, mianował go naczelnym dowódcą ${ }^{17}$.

W latach 1620-1627 nieograniczoną władzę nad Czechami sprawował Karol z Lichtensteinu, zaś na Morawach kardynał Ditrichstein. Na okres ten przypada początek rekatolizacji Królestwa Czech. Duchownych czeskobraterskich wygnano z kraju już w 1621 r., rok później podobny los spotkał kaznodziejów ewangelickich. Uniwersytet Karola oddano pod kontrolę jezuitom, a z czasem połączono z kolegium jezuickim, tworząc nowy Uniwersytet Karola-Ferdynanda. Władza namiestników królewskich nie cieszyła się poparciem nawet wśród katolickiej szlachty i cesarz nie mógł na niej specjalnie polegać, co sprawiło, że 10 maja 1627 r. wydał dla Czech nową konstytucję, znaną jako Odnowiony ustrój ziemski. W dniu 1 lipca 1628 r. podobny dokument wydano dla Moraw. Nowe zasady ustrojowe nie objęły Śląska, gdzie rządzili na wpół niezależni książęta, z których część była protestantami $^{18}$. Rekatolizacja nie dotknęła też Łużyc, które w 1624 r. stały się lennem elektora saskiego.

Ferdynand II wychodził z założenia, że wzniecając „nikczemną rebelię”, czeskie stany same sobie odebrały przynależne prawa i że tylko od niego zależy, czy zechce odnowić część z nich. Odnowiony ustrój ziemski był wyłącznie wyrazem woli monarchy, wprowadzonym bez jakiejkolwiek konsultacji ze stanami. Fundamentalną zmianą było uznanie Habsburgów za dziedzicznych władców Czech, co oznaczało, że nowy król wstępował na tron wraz ze śmiercią poprzedniego, a sama koronacja miała jedynie symboliczne znaczenie. Elekcja króla czeskiego nie została formalnie zakazana, niemniej z tekstu wynikało explicite, że możliwa jest wyłącznie w przypadku wygaśnięcia dynastii habsburskiej, i to także w linii żeńskiej. W kwestiach religijnych przyjęto, że w kraju nie może mieszkać nikt, kto różni się z władcą pod względem wyznania, a więc nie jest katolikiem. Odnowiono sejmy ziemskie, a obok dotychczasowych trzech stanów wprowadzono nowy pierwszy stan - prałacki, składający się z arcybiskupów, biskupów i przedstawicieli niektórych zakonów posiadających majątki ziemskie. Na Morawach przedstawiciele duchowieństwa już wcześniej brali udział w sejmach ziemskich, teraz, podobnie jak w Czechach, podwyższono ich do rangi stanu pierwszego. $Z$ kolei mieszczanie jako stan całkowicie stracili na znaczeniu, ponieważ wszystkie miasta dysponowały odtąd w sejmach tylko jednym głosem. Istotne zmiany nastapiły w uprawnieniach i pozycji sejmów, które mogły zajmować się wyłącznie projektami złożonymi przez króla, samemu nie mając inicjatywy ustawodawczej. Dopiero w 1640 r., za rządów Ferdynanda III, wprowadzono zasadę, że sejm może z własnej woli zajmować się drobniejszymi sprawami, niemającymi charakteru politycznego, jak

\footnotetext{
${ }^{17}$ Czeską biografię patrz: J. Polišenský-J.Kollman, Valdštejn. Ani císař, ani král, 2. vyd., Praha 2001.

${ }^{18} \mathrm{~W}$ imieniu Ferdynanda II elektor saski Jan Jerzy zawarł 28 lutego 1621 r. w Dreźnie traktat ze zbuntowanymi stanami śląskimi, gwarantujący im przywileje sprzed bitwy pod Białą Górą, jeśli uznają władzę cesarza i zapłacą kontrybucję w wysokości 300000 złotych.
} 
budowa dróg czy regulacja rzek. Sejm utrzymał tylko jedną istotną kompetencję, mianowicie pozwalał królowi na pobieranie podatków. Poza tym każde prawo wydane przez króla miało moc obowiązującą i nie musiało być uchwalane przez sejm. Odnowiony ustrój ziemski wprowadzał więc faktycznie absolutyzm, co widać było zwłaszcza na tych obszarach, gdzie monarcha musiał się wcześniej liczyć ze zdaniem stanów. Odtąd monarcha sam mógł decydować o nobilitacji czy udzielaniu indygenatu, a nawet tam, gdzie pozostawiono dawne szlacheckie instytucje, podporządkowano je całkowicie woli monarchy. Wojewodowie (,hetmani”), choć nadal wybierani przez miejscową szlachtę, musieli składać przysięgę królowi, monarcha decydował o składzie królewskiego sądu apelacyjnego, którego wyroki były odtąd obowiązujące dla wszystkich sądów w kraju, a także o składzie czeskiej kancelarii dworskiej, którą w 1624 r. na stałe przeniesiono do Wiednia. Odnowiony ustrój ziemski wprowadzał równouprawnienie języka niemieckiego i czeskiego.

Nowa organizacja państwa dotknęła przede wszystkim czeskich i morawskich protestantów, niezależnie, czy chodziło o ewangelików, Braci czeskich czy inne nieoficjalne i dotąd tolerowane wyznania, jak choćby morawskich neobaptystów, habanów ${ }^{19}$. Chcąc pozostać w kraju, musieli w ciagu pół roku przejść na katolicyzm, bowiem jeśli tego nie uczynili, musieli wyprzedać swój majątek i wyjechać za granicę. Prawo swobodnej emigracji nie dotyczyło jednak ludności poddanej, tej z góry narzucono konwersję. Istniały pewne wyjątki, w których niekatolikom pozwalano zachować, z reguły na pewien tylko czas, dotychczasową wiarę, bez konieczności opuszczenia kraju. Działo się tak jednak wyłącznie na podstawie indywidualnej decyzji cesarza. Ewangelików tolerowano na Śląsku i w trzech miastach na cyplu askim, stanowiących lenno Świętej Rzeszy Rzymskie (Świętego Cesarstwa Rzymskiego Narodu Niemieckiego). W Czechach w spokoju pozostawiono Żydów, traktowanych jako ważne źródło zysków. Cesarz wziął też zapewne pod uwagę fakt, że na początku powstania protestanci dopuścili się antyżydowskich pogromów, a Żydzi pozostali wierni Habsburgom. Strumień uchodźców płynął przede wszystkim do Saksonii, na Łużyce, Śląsk i Słowację, której nie objęto przymusową rekatolizacją, bliskość granicy tureckiej wymuszała bowiem prowadzenie racjonalnych i umiarkowanych działań.

Centrum czeskiej emigracji stało się także polskie Leszno, gdzie przez pewien czas działał ostatni biskup wspólnoty braterskiej, Jan Ámos Komenský (Komeniusz, 1592-1670). Uchodźcy próbowali zainteresować swoim losem protestanckie państwa Europy, przeciwników Habsburgów, przede wszystkim Szwecję i Holandię (Komeniusz przebywał w obu tych krajach, zresztą w Holandii zmarł), wierząc, że antyhabsburska koalicja ostatecznie zwycięży, a oni będą mogli powrócić do swych domów.

Do dziś przedmiotem sporów pozostaje pytanie, jak wielu czeskich protestantów zdecydowało się na emigrację. Według niepełnych danych mogło chodzić o 36 tysięcy rodzin szlacheckich i mieszczańskich, a więc o mniej więcej 150 tys. osób. Wiadomo jednak, że trzeba do tego doliczyć nieznaną liczbę ludności poddanej, która mimo zakazu także uciekła z kraju. Co więcej, w związku z czasową okupacją Czech przez wojska saskie i szwedzkie w okresie wojny trzydziestoletniej, część emigrantów wróciła, by ponownie opuścić

${ }^{19}$ Przybyli ze Szwajcarii habanie (czes. habáni) byli bardzo zdolnymi rzemieślnikami, zwłaszcza odnosili sukcesy w uprawie winorośli, sprowadzając na Morawy nowe szczepy i przyczyniając się do rozwoju morawskiego winiarstwa. Jest kilka hipotez dotyczących ich nazwy, którą wywodzi się od niem. Haus haben, „mieć dom", staroniem. Habaner, garncarz lub hebr. ha-banim, synowie (przyp. thum.). 
ojczyznę po zawarciu pokoju westfalskiego wraz z tymi, którzy po 1627 r. przeszli na katolicyzm tylko dla zachowania pozorów. Można zatem przyjąć, że w omawianym okresie Czechy opuściło ok. 200000 osób. Pamiętajmy też, że wśród emigrantów nie byli wyłącznie etniczni Czesi, ale także niemieccy ewangelicy, głównie z Rudaw, którzy osiedli w Saksonii, asymilując się z tamtejszą ludnością. Czescy protestanci byli częścią elity kulturalnej, z tego choćby punktu widzenia rekatolizacja stanowiła poważną stratę. Dzisiejsi Czesi nie są potomkami ewangelików czy Braci czeskich, ci bowiem opuścili ojczyznę, lecz katolików i tych, którzy po 1627 r. zmienili wyznanie.

\section{Wojna trzydziestoletnia}

Po stłumieniu powstania stanowego, które jako etap wojny trzydziestoletniej nazywane jest fazą czeska, walki przeniosły się do Palatynatu, dóbr Fryderyka V Wittelsbacha. Jednocześnie przeciwko cesarzowi stanął książę Karniowa, Jan Jerzy Hohenzollern, którego, za zgodą Turcji, wsparł Gábor Bethlen ${ }^{20}$. Wojskom cesarskim udało się zająć Palatynat, a Fryderyk został pozbawiony głosu elektorskiego, który przekazano Maksymilianowi Bawarskiemu, i wyjechał do Hagi, gdzie zmarł w 1632 r. Pokój zawarty w 1622 r. w Mikulovie na Morawach zabezpieczał z kolei sytuację na wschodzie - Gábor Bethlen zrzekł się tytułu króla Węgier, za co otrzymał w dożywotnie posiadanie siedem komitatów na północy Siedmiogrodu oraz na wschodzie obecnej Słowacji i na Ukrainie Zakarpackiej. Później kilkukrotnie próbował rozszerzyć swe władztwo, jednak bez rezultatów - traktaty podpisane w Wiedniu w 1624 r. i Bratysławie dwa lata później jedynie potwierdzały wcześniejsze ustalenia.

Nowym przeciwnikiem Habsburgów stała się Dania, wspierająca niemieckich protestantów. W dniu 19 grudnia 1625 r. w Hadze utworzono związek Anglii, Danii, Holandii i Dolnej Saksonii, wymierzony przeciwko hiszpańskim i austriackim Habsburgom. Na czele związku, którego członkiem został także „król Czech i elektor Palatynatu” Fryderyk, stanął duński król Chrystian IV. Dało to początek nowemu etapowi wojny trzydziestoletniej zwanemu fazą duńską (1625-1629). Armia koalicji antyhabsburskiej została co prawda pokonana w bitwie pod Lutter w Dolnej Saksonii 27 sierpnia 1626 r., jednak Duńczykom udało się dotrzeć na Śląsk i Morawy. W tym samym czasie Bethlen rozpoczął kolejną wyprawę na Wiedeń, został jednak zatrzymany przez armię Albrechta Wallensteina i zmuszony do podpisania kolejnego pokoju. Próbę zdobycia Wiednia podjęli także Duńczycy, ale i ona skończyła się niepowodzeniem. Dania prowadziła w tym czasie wojnę ze Szwecją i nie mogła zaangażować w Austrii wystarczających sił. Sytuację wykorzystał Wallenstein, rzucając swoją armię w kierunku Niemiec i stopniowo opanowując niemal całe ich terytorium. Armia cesarska zatrzymała się dopiero nad brzegiem Bałtyku, pod murami ufortyfikowanego portu w Stralsundzie.

Faza duńska wojny trzydziestoletniej była szczytem potęgi Albrechta Wallensteina. Wszędzie, gdzie dotarła dowodzona przez niego armia, nakładano kontrybucje, które trafiały wprost do jego kieszeni jako spłata długu, który zaciągnął u niego cesarz. Można

${ }^{20}$ Biografię Jana Jerzego patrz: R. Fukala, Jan Jiři Krnovský. Stavovské povstání a zápas s Habsburky, České Budějovice 2005. 
powiedzieć, że nieprzyjaciele Habsburgów sami finansowali wojnę przeciwko sobie. Skupując konfiskowane majątki, Wallenstein zgromadził ogromne dobra, sięgające od północnych granic Czech aż do centrum państwa. Terytorium to nazywano województwem frýdlandzkim, od miasta i zamku Frýdland, położonego na północ od Liberca. Jednak „stolicą” dóbr Wallensteina, które stało się niejako państwem w państwie, był Jiczyn, o którego rozwój cesarski dowódca szczególnie dbał. Cesarz mianował Wallensteina ,admirałem Bałtyku i Oceanu" oraz wojewodą frýdlandzkim, podniósł go także do stanu hrabiów Rzeszy z prawem nobilitowania swoich poddanych i wybijania własnej monety. Albrecht Wallenstein był nie tylko znakomitym dowódca, ale i sprawnym gospodarzem, który zapewnił swoim ziemiom rozwój ekonomiczny. W Pradze wybudował przepiękny pałac na Malej Stranie, tuż u stóp zamku ${ }^{21}$.

Sukcesy militarne w Niemczech pchnęły cesarza ku planom wzmocnienia tam swojej władzy, co wiązało się ze wzmocnieniem pozycji Kościoła katolickiego. Ferdynand II wydał edykt restytucyjny, w którym nakazywał książętom protestanckim zwrot majątku zabranego niegdyś Kościołowi. Wywołało to ich oczywisty sprzeciw, na tyle silny, że cesarz musiał zdecydować się na ustępstwa. Jednym z nich była dymisja Wallensteina.

Po zakończeniu wojny z Danią przeciwko potędze Habsburgów stanęła i Szwecja. Król Gustaw II Adolf, występując w roli obrońcy protestantów, przeprowadził desant na wybrzeża Niemiec, rozpoczynając kolejny etap europejskiego konfliktu - fazę szwedzką. Armia szwedzka wyzwoliła najpierw Stralsund, wciąż oblegany przez wojska cesarskie, a następnie ruszyła na południe. Zadanie zdobycia Czech powierzono elektorowi saskiemu, który został sojusznikiem Szwecji, a sam Gustaw Adolf skierował się do Bawarii, zdobywając po drodze Magdeburg. Celem było Monachium, siedziba Maksymiliana Bawarskiego, które także udało się Szwedom zdobyć.

Sasi rozpoczęli swoją kampanię w 1631 r. i szybko wkroczyli do Pragi. Wraz z nimi do Czech wróciła spora część emigrantów. Z wieży mostowej zdjęto wówczas głowy ściętych przed laty powstańców i uroczyście je pochowano. Cesarz, nie mając innego wyjścia, ponownie postawił Wallensteina na czele swojej armii. Ten w 1632 r. odbił Pragę a wkrótce wypchnął Sasów z Czech, wkraczając za nimi do Niemiec. Dnia 16 listopada Wallenstein starł się z armią szwedzką pod Lützen, niedaleko Lipska. Trwająca siedem godzin bitwa nie przyniosła rozstrzygnięcia, jednak obie strony poniosły poważne straty. W bitwie padł król Szwecji, Gustaw II Adolf.

Mimo powrotu do wielkiej polityki Wallenstein nie czuł się usatysfakcjonowany. Za pośrednictwem swoich oficerów nawiązał tajne kontakty z dowództwem szwedzkim i czeskimi emigrantami, którzy nawet zaoferowali mu koronę w razie pokonania Habsburgów. Zachowane źródła nie pozwalają stwierdzić, co dokładnie zawierało porozumienie między Wallensteinem i Szwedami, i jak dalece poważnie myślał on o czeskim tronie. W każdym razie w 1633 r. prowadził dość pozorowaną wojnę ze Szwedami, wyraźnie licząc się z nimi w swych politycznych planach. Jego postawa wzbudziła w końcu podejrzenia Ferdynanda, podburzanego jeszcze przez przeciwników Wallensteina. Ten, wciąż nie decydując się na otwarty bunt przeciwko cesarzowi, tracił tylko cenny czas. Wreszcie na początku 1634 r. Ferdynand odwołał swego dowódcę i nałożył na niego cesarską infamię, co w prak-

${ }^{21}$ Dziś siedziba czeskiego Senatu. Dostępny dla zwiedzających ogród jest jedną z turystycznych atrakcji Pragi (przyp. tłum.). 
tyce oznaczało, że każdy mógł go bezkarnie zabić. Wallensteinowi, którego opuściła większość oficerów, nie pozostało nic innego, jak przebić się do Szwedów, stacjonujących wówczas niedaleko czeskich granic. 25 lutego przybył ze swą drużyną do nadgranicznego Chebu. Na noc zatrzymał się w jednej z mieszczańskich kamienic w rynku, a jego współtowarzysze zajęli miejscowy zamek. Do pozycji szwedzkich miał już niedaleko, jednak nigdy do nich nie dotarł. Pod osłoną nocy grupa wiernych cesarzowi oficerów wraz z oddziałem wojska zdobyła zamek i opanowała miasto. Wallenstein został zamordowany, a wraz z nim życie stracili jego najbliżsi towarzysze. Jego olbrzymi majątek został skonfiskowany i rozdzielony między cesarskich oficerów, w pierwszym rzędzie tych, którzy przeprowadzili całą akcję. Trafił on głównie w ręce zagranicznej szlachty, co, uwzględniając wielkość majątku, wpłynęło istotnie na społeczne i etniczne stosunki w Czechach ${ }^{22}$.

Ferdynand II postanowił osłabić sojusz szwedzko-saski. Negocjacje cesarza z elektorem Janem Jerzym okazały się owocne i Saksonia wycofała się z wojny, za co, na mocy pokoju praskiego z 1635 r., otrzymała Łużyce. Cesarz jako król czeski zastrzegł sobie jedynie prawo nadzoru lennego nad tymi ziemiami, niemające w praktyce żadnego znaczenia. Pokój praski oznaczał ostateczną utratę Łużyc przez Czechy i zmniejszenie terytorium Korony. Jednocześnie Ferdynand zobowiązał się przestrzegać praw religijnych książąt śląskich, w zamian za co Jan Jerzy obiecał, że przestanie wspierać czeskich ewangelików.

Układ z Saksonią nie przyniósł jednak Czechom pokoju. Szwedzki kanclerz Axel Oxenstierna, który rządził w imieniu nieletniej córki Gustawa Adolfa, Krystyny, zdecydował się na kontynuowanie walki. W miejsce słabej Saksonii Szwedzi znaleźli sobie nowego sojusznika, Francję, także zaniepokojoną rosnącą potęgą Habsburgów. Sojusz protestanckiej Szwecji z katolicką Francją pokazał, że kwestie religijne przestały mieć w tej wojnie jakiekolwiek znaczenie, a jej prawdziwym celem jest pokonanie Habsburgów. Podczas gdy Francja miała walczyć w Hiszpanii, Szwecja skupiła się na środkowej Europie. Po ponownym desancie w Niemczech szwedzka armia podzieliła się na dwie części, z których jedna ruszyła w kierunku Bawarii i Austrii, druga zaś wprost do Czech. Szwedzko-francuska, ostatnia faza wojny trzydziestoletniej rozgrywała się w przeważającej części właśnie na czeskim terytorium i przyniosła największe straty nie tyle wśród żołnierzy, ile przede wszystkim ludności cywilnej. Nie było przy tym różnicy, czy przez Czechy przechodziła armia szwedzka, czy cesarska. Zgodnie z powiedzeniem „wojna żywi się sama”, obie armie bezlitośnie łupiły miejscową ludność.

Ferdynand II nie doczekał końca wojny, jako że zmarł w 1637 r. Jego syna i następcę, Ferdynanda III (1637-1657), różnił od ojca zwłaszcza brak religijnego fanatyzmu. Nie zaniechał wprawdzie planu całkowitej rekatolizacji Czech, odłożył go jednak w czasie i zdecydował się przeprowadzić łagodniejszymi środkami. Nie był dotknięty traumą ,nikczemnej rebelii", zachowując pozytywny stosunek do Czechów (całkiem dobrze władał językiem czeskim). Swego syna, Ferdynanda IV, ogłosił królem Czech, ten jednak zmarł jeszcze za życia ojca.

Pierwszy atak na Czechy Szwedzi przeprowadzili w kwietniu 1639 r. Dowódca armii szwedzkiej, gen. Johann Banner, wydał w Litomierzycach proklamację, w której ogłosił

\footnotetext{
${ }^{22} \mathrm{Na}$ temat śmierci Wallensteina patrz: K. Pekař, Dějiny valdštejnského spiknutí, 3. vyd., Praha 2008; J. Janáček, Valdštejn a jeho doba, 2. vyd., Praha 2003; J. Kollman, Valdštejnův konec. Historie druhého generalátu, Praha 2001.
} 
się obrońcą czeskich protestantów, jednak większość społeczeństwa nie widziała w nim wyzwoliciela, zachowując wrogi stosunek do najeźdźców. Były to już inne czasy, Czechy były w istocie państwem katolickim, a kwestie religijne nie odgrywały już tak istotnej roli. Na początku maja Szwedzi podeszli pod Pragę, ta jednak bohatersko się broniła. Ramię w ramię z armią cesarską stanęły przeciwko nim straże miejskie i studenci uniwersytetu. Własny oddział wystawili także prascy Żydzi, wykazując się w walce nie lada odwagą. Wspólnymi siłami udało się odepchnąć Szwedów spod murów miasta, a wiosną $1640 \mathrm{r}$. wyzwolić całe Czechy.

Po raz kolejny Szwedzi spróbowali szczęścia w 1642 r., pokonując 1 czerwca armię cesarską pod Świdnica, co otworzyło im drogę na Morawy. Dwa tygodnie później, po czterodniowym oblężeniu, padł Ołomuniec, następnie kilka innych północnomorawskich miast. Wsparcia udzielili Szwedom protestanccy Wałasi, wolny lud pasterski zamieszkujący Beskidy, którego pochodzenie nie jest do końca jasne ${ }^{23}$. W latach 1633-1634 Wałasi wzniecili otwarty bunt i przy szwedzkiej pomocy opanowali część środkowych Moraw. W kwietniu 1643 r. armia gen. Lenarda Torstenssona ruszyła z Łużyc na Czechy, skąd planowała uderzyć na Wiedeń. Sytuacja wydawała się im sprzyjać, bowiem na Węgrzech wybuchło właśnie nowe powstanie antyhabsburskie pod wodzą Jerzego Rakoczego. Armia szwedzka, szybko postępując w głąb Czech, tym razem ominęła Pragę. Do decydującej bitwy doszło 6 marca 1645 r. we wsi Jankov, między Kolínem a Taborem. Armia cesarska, dowodzona przez generałów Hatzfeldta i Götza, została rozbita w pył, a sam Götz poległ. Niedobitki wycofały się na wschód, w kierunku Brna, bronionego jedynie przez niewielką załogę i mieszczan. Szwedom nie udało się jednak zdobyć miasta, a niepowodzenie to kazało im odstąpić także od marszu na Wiedeń.

W latach 1645-1648 Czechy i Morawy pozostawały rozdzielone na dwie części: północ kontrolowali Szwedzi, południe - armia cesarska. W międzyczasie Ferdynandowi udało się zakończyć powstanie na Węgrzech. Na mocy pokoju w Linzu obiecał tamtejszym stanom protestanckim zachowanie swobód religijnych. Siły Szwedów i Habsburgów wydawały się wyrównane i żadna ze stron nie mogła być pewna zwycięstwa. W tym czasie w Münster i Osnabrück w Westfalii prowadzono już rozmowy pokojowe. Szwedzi, by wzmocnić swoją pozycję w negocjacjach, postanowili zająć Pragę. Okazja nadarzyła się w 1648 r., gdy niejaki pułkownik Otovalský zbiegł z armii cesarskiej i zaoferował im swoje usługi. Wiedział, że część murów obronnych na wzgórzu Petřín jest mocno uszkodzona i w nocy z 24 na 25 lipca przeprowadził tamtędy po kryjomu trzystu szwedzkich żołnierzy. Ci pokonali malostranskie straże i otworzyli bramy miasta nadchodzącej armii. Szwedzi zajęła Malą Stranę i Hradczany, łupiąc zamek, a następnie ruszyli na most Karola, by przedostać się na drugi brzeg Wełtawy. Tu jednak napotkali na silny opór, zwłaszcza praskich studentów dowodzonych przez jezuitę Jerzego Plachę, i miejscowych Żydów ${ }^{24}$. Nim Szwedzi zdecydowali się na kolejną próbę zdobycia mostu, nadeszła wiadomość, że 24 września podpisano w Osnabrück układ pokojowy. W ten sposób wielki europejski konflikt zaczął się i skończył w Pradze. Szwedzka okupacja Malej Strany trwała jeszcze do momentu ratyfikowania pokoju w 1650 r. Szwedzi nie próżnowali w tym czasie, łupiąc

\footnotetext{
${ }^{23}$ Pochodzenie Wałasów bywa kojarzone z rzekomą kolonizacją Beskidów przez pasterską ludność przybyłą z Bałkanów, zwłaszcza z Rumunii. Teoria ta nie została jednak nigdy dostatecznie potwierdzona.

${ }^{24}$ T. Pěkný, Historie Žido̊ v Čechách a na Moravě, Praha 1993, s. 69.
} 
co się da. Na rozkaz królowej Krystyny wywieźli z zamku bezcenne obrazy z kolekcji cesarza Rudolfa, a z klasztoru na Strahovie księgi i rękopisy. Plądrowane były także pałace szlacheckie i mieszczańskie kamienice. Wywiezione wówczas z Pragi łupy nigdy do niej nie powróciły, większość znajduje się w muzeum Uniwersytetu w Uppsali ${ }^{25}$.

\section{Pokój westfalski}

Układy podpisane w Osnabrück i Münster, nazywane pokojem westfalskim, negocjowane były z przerwami przez kilka lat. Uregulowały one stosunki w Cesarstwie i Europie Środkowej w kształcie, który przetrwał do XVIII w. Podstawą pokoju westfalskiego był kompromis między Habsburgami austriackimi a Szwecją i Francją. Układ nie dotyczył trwającej wojny między Francją a Hiszpanią, która zakończyła się dopiero w 1659 r. Habsburgowie musieli porzucić plany odbudowy realnej władzy w Świętym Cesarstwie, bowiem niemieccy książęta i wolne miasta zyskały prawo zawierania umów międzynarodowych, z tym jednak zastrzeżeniem (w praktyce niedającym się zrealizować), że nie będą one wymierzone przeciwko Cesarstwu i cesarzowi. W pewnym uproszczeniu można by stwierdzić, że pozycję, którą de iure miało w ramach Cesarstwa tylko Królestwo Czeskie, zyskały odtąd wszystkie niemieckie państwa. Święte Cesarstwo Rzymskie Narodu Niemieckiego, z którego wyłączono Szwajcarię i Holandię, definitywnie rozpadło się na setki państw i państewek, nad którymi cesarz nie miał już żadnej władzy. Każda decyzja cesarza wymagała zgody sejmu Rzeszy, zbierającego się z reguły w Ratyzbonie. Francja i Szwecja za sprawą swoich zdobyczy terytorialnych w Rzeszy stały się gwarantem tego stanu rzeczy. W kwestiach religijnych zachowano uzgodnienia pokoju augsburskiego, przy czym zasada „czyj kraj, tego religia” miała obejmować także konfesję kalwińską. Jako że w trakcie wojny doszło do szeregu zmian na religijnej mapie Cesarstwa, wprowadzono dodatkowy zapis, zgodnie z którym ludność mogła zachować to wyznanie, któremu za zgodą swego władcy pozostawała wierna przed 1624 r. Pokój uznawał kwestie religii za wewnętrzną sprawę każdego z państw, tak by nie stanowiły już więcej podłoża konfliktów. Każdy władca miał pełne prawo, uwzględniając lokalne warunki, regulować stosunki wyznaniowe podług swego uznania i tylko od niego zależało, czy zmusi swych poddanych, by przyjęli jego wiarę, czy też pozwoli im zachować swoją. Pokój westfalski potwierdzał w ten sposób religijną różnorodność Europy i z tego powodu nigdy nie został uznany przez papieża.

Podczas gdy w Cesarstwie wpływy Habsburgów spadły praktycznie do zera, w swych rodowych dobrach, Austrii i Czechach, dostali wolną rękę. Na tym polegała druga część kompromisu westfalskiego, osiagniętego kosztem czeskich protestantów. Emigranci z Czech wszelkimi dostępnymi środkami próbowali wpłynąć na przedstawicieli niemieckich państw protestanckich, a przede wszystkim na Szwedów, by pamiętali o ich interesach i jeśli już nie da się strącić Habsburgów z czeskiego tronu, to żeby choć zagwarantować protestantom amnestię i powrót do domów. Pierwotnie szwedzka delegacja faktycznie zamierzała upo-

${ }^{25}$ Znajdują się tam także bezcenne księgozbiory wywiezione z Polski podczas Potopu, w tym księgi należące niegdyś do Mikołaja Kopernika z jego odręcznymi notatkami. W jednej z nich w 2008 r. znaleziono włos, który istotnie pomógł w ustaleniu miejsca pochówku astronoma, stanowiąc materiał porównawczy dla badań DNA (przyp. tłum.). 
mnieć się o czeskich protestantów, ale gdy tylko okazało się, że Ferdynand III nie zamierza o nich dyskutować, porzucono ten temat. Potomkom Zimowego króla zwrócono co prawda Palatynat i głos elektorski (elektorów Rzeszy było odtąd ośmiu, zamiast siedmiu), jednak za cenę zrzeczenia się jakichkolwiek roszczeń do korony czeskiej. Habsburgom dano prawo władania w ich rodowych dobrach według własnego uznania, łącznie z możliwością narzucenia swoim poddanym wyznania. Stosunki religijne w Czechach i na Morawach miały zostać ustalone na podstawie sytuacji z roku 1624, a więc podobnie jak w innych państwach Rzeszy, co bezsprzecznie oznaczało dominującą pozycję religii katolickiej ${ }^{26}$. Emigrantom czeskim faktycznie udzielono amnestii, jednak do ojczyzny mogli wrócić jedynie pod warunkiem ,uznania praw krajowych”, a więc przejścia na katolicyzm. Zasada „czyj kraj, tego religia” pomogła jedynie protestantom ze Śląska, podległym miejscowym książętom. Swobodę religijną zachowano także na Węgrzech, według zapisów pokoju z Linzu, te nie należały bowiem do Świętego Cesarstwa.

\section{Skutki wojny trzydziestoletniej i mit bialogórski}

Podczas gdy w XVII i XVIII w. bitwa pod Białą Górą była symbolem zwycięstwa nad heretykami i powrotu Czech do Kościoła, w wieku XIX stała się synonimem końca czeskiej państwowości i ,bezgranicznej tragedii narodu”. Czesi przyjęli interpretację, którąjeszcze w czasie wojny propagowała emigracja protestancka i to bez względu na to, że w XIX w. Czechy w ponad 80 procentach były krajem katolickim. Dla działaczy okresu odrodzenia narodowego Biała Góra zyskała rys narodowościowy i podobnie jak husytyzm postrzegana była jako element walki Czechów z Niemcami i początek „obcego jarzma”, mimo że Habsburgowie rządzili w Czechach już sto lat wcześniej. Obraz Białej Góry jako końca czeskiej państwowości pokutuje właściwie do dziś27 ${ }^{27}$. Interesujące jest przy tym, że takiego poglądu nie wyraził dosłownie żaden z czołowych historyków czeskich XIX i XX w., chociaż, poczynając od Palackiego, zgadzali się oni, że bitwa białogórska miała negatywny wpływ na bieg czeskiej historii ${ }^{28}$. Upadek powstania stanowego był często konfrontowany z sukcesem rewolucji husyckiej. Historiografia marksistowska lat pięćdziesiątych podkreślała przy tym, że powstanie musiało skończyć się katastrofą, nie reprezentowało bowiem interesów ludu, a jedynie szlachty i mieszczaństwa. Po drugiej wojnie światowej komuniści chętnie mówili o „zdradzie”, jakiej wobec sprawy czeskiej dopuściła się w latach 1618-1620 Anglia i Francja, przywołując w tym kontekście rok 1938 i układ monachijski.

W istocie Biała Góra oznaczała przede wszystkim zastąpienie koncepcji monarchii stanowej nowocześniejszą koncepcją rządów absolutystycznych, w której szlachta nadal zachowała pewien wpływ na losy państwa (tzw. imperium mixtum). W kwestiach religijnych przyniosła koniec tezy o możliwym współistnieniu różnych wyznań chrześcijańskich i wprowadzała w jej miejsce powszechną w ówczesnej Europie zasadę wymuszonej jed-

\footnotetext{
${ }^{26}$ Był to podstawowy powód, dla którego Habsburgowie obstawali za tym właśnie rokiem. Pierwotna propozycja Szwecji przyjmowała za podstawę ułożenia stosunków wyznaniowych w Czechach rok 1618.

${ }^{27}$ J. Rychlík, Bitva na Bílé Hoře a mýtus o třistaleté porobě, [w:] Literární mystifikace, etnické mýty a jejich úloha při formování národního vědomí. Studie Slováckého muzea, 6, 2001, s. 85-94.

${ }^{28}$ F. Palacký, Dějiny národu českého v Čechách a v Moravě dle původních pramenův, I, 5. vyd., Praha 1933, s. 21.
} 
ności religijnej. Bitwa pod Białą Górą nie była również końcem czeskiej państwowości, przynajmniej nie w znaczeniu formalnym. I po niej Habsburgowie rządzili w Czechach jako królowie czescy, tak samo jak ich poprzednicy od 1526 r. Szczególna pozycja Królestwa Czeskiego wśród ziem należących do Habsburgów nie tylko nie została zniesiona, ale wręcz potwierdzona na mocy Odnowionego ustroju ziemskiego. Z drugiej strony jest oczywiste, że wprowadzenie absolutyzmu otworzyło drogę do stopniowego zbliżenia ziem czeskich i austriackich, stąd w dziejach budowy nowoczesnego państwa austriackiego bitwa pod Białą Górą była niewątpliwie ważnym momentem. Zanik państwowości czeskiej był długim procesem i tylko od naszych poglądów i ocen zależy, jak wyznaczymy jego czasowe granice. Początek można by dostrzec w roku 1526 i likwidacji czesko-węgiersko-austriackiej unii personalnej ${ }^{29}$, koniec pozostaje mniej oczywisty, wydaje się jednak, że nastąpił on dopiero gdzieś w połowie XVIII w. ${ }^{30}$

Podobnie błędne jest utożsamianie Białej Góry z walką Czechów z Niemcami i twierdzenie, że wynik bitwy otworzył drogę germanizacji. Po stronie stanów czeskich walczyli i etniczni Niemcy, protestanci (Schlick, Thurn), po stronie Ferdynanda przedstawiciele czeskojęzycznej szlachty (Slavata, Martinic, Lobkovicowie). Czechy na długo przed Białą Górą były krajem dwujęzycznym (dotyczyło to zwłaszcza miast), a dwa województwa (chebskie i loketskie) były czysto niemieckie. Podobnie było na Morawach. Starsi historycy błędnie interpretowali sens postanowień Odnowionego ustroju ziemskiego, dotyczących równouprawnienia języka niemieckiego i czeskiego, przeciwstawiając je decyzji sejmu ziemskiego z 1615 r., także błędnie interpretowanej, uznającej znajomość czeskiego za warunek indygenatu. Prawo to potwierdza jedynie, że już przed Białą Górą na terytorium Czech język niemiecki był w powszechnym użyciu, a ze znajomością czeskiego wśród wyższych warstw bywało różnie. Logika jest prosta: gdyby wszyscy władali czeskim, nie byłoby potrzeby przyjmować takiego prawa. Decyzje z 1615 r. nigdy nie zostały wdrożone w całości, a właśnie w czasie powstania stanowego dwujęzyczność stała się oczywistością. Od roku 1618 r. nawet obrady Sejmu odbywały się w obu językach, rozpoczynały je z reguły modlitwy po czesku i po niemiecku. Uprawomocnienie dwujęzyczności na mocy Odnowionego ustroju ziemskiego było zatem tylko potwierdzeniem istniejącego stanu rzeczy. Josef Pekař w swojej pracy o bitwie pod Białą Górą wyraził nawet pogląd, że tylko wzmocniła ona czeski żywioł, bowiem czescy protestanci kształcili się z reguły na niemieckich uniwersytetach, co w razie ich zwycięstwa znacząco rozszerzyłoby wpływy języka niemieckiego w Czechach ${ }^{31}$. Wzrost żywiołu niemieckiego spowodowany był dopiero kolonizacją wyludnionych ziem czeskich po wojnie trzydziestoletniej i sprowadzeniem osadników z niemieckich państw katolickich.

Pokój westfalski, podobnie jak bitwa pod Białą Góra, uznawany jest za akt skrajnej niesprawiedliwości, bowiem w trakcie pierwszego w dziejach Europy kongresu między-

${ }^{29}$ Historiografia węgierska widzi koniec samodzielności państwowej Węgier w bitwie pod Mohaczem w 1526 r., co jest dziwne, bowiem tamtejsza monarchia stanowa utrzymała się dłużej niż czeska, a Węgry w znacznie większym stopniu zachowały swą pozycję w ramach monarchii habsburskiej.

${ }^{30}$ Josef Pekař pisał tak: „Czy zatem katastrofie białogórskiej w ogóle nie można przypisać winy za utratę czeskiej państwowości? Owszem, można, ale winę pośrednią i odłożoną w czasie. Biała Góra jedynie dała początek wydarzeniom, które doprowadziły do utraty państwowości, ale nie taki miał być jej skutek”. Zob. J. Pekař, Bílá Hora, [w:] O smyslu českých dějin, 3. vyd., Praha 1990, s. 201.

${ }^{31}$ J. Pekař, O smyslu..., s. 207-208. 
narodowego rozmawiano o Czechach bez Czechów. W drugiej połowie XX w. pojawiła się dodatkowo paralela, oparta na politycznych motywacjach, między postawą mocarstw zachodnich w Osnabrück w 1648 r. i w Monachium w roku 1938. Z tego porównania wyciagano wniosek, że mocarstwa zachodnie zawsze chętnie sprzedadzą Czechów w imię własnych interesów. Tego typu dywagacje są ahistoryczne, ponieważ dotyczą dwóch całkowicie odmiennych epok. Faktem jest, że pokój westfalski potwierdził skutki bitwy białogórskiej, pozwolił na dokończenie rekatolizacji Czech, wzmocnienie absolutyzmu, a w dalszej perspektywie stopniowe zjednoczenie ziem czeskich i austriackich. Pokój westfalski przez to, że nie uznawał postanowień pokoju augsburskiego na ziemiach czeskich, wyznaczył wyraźną granicę między Królestwem Czeskim a innymi państwami Świętego Cesarstwa.

Zastanówmy się jeszcze na koniec nad wpływem wydarzeń z lat 1618-1648 na rozwój sytuacji politycznej i kulturę. W środowiskach czeskich, pod wpływem XIX-wiecznych dyskusji politycznych, panuje przekonanie, że monarchia stanowa sprzed roku 1618 (ewentualnie 1620) dawała gwarancję wolności i niezależności. Ówczesny ustrój państwa bywa uważany za coś w rodzaju „wczesnej nowożytnej demokracji”, stojącej w opozycji do „obcego” absolutyzmu habsburskiego. To kolejne nieporozumienie. Monarchia stanowa nie ma nic wspólnego z demokracją. Co więcej, w tym kształcie, który nadała jej konfederacja stanów czeskich z 1619 r., nie rozwinęłaby się w parlamentaryzm i monarchię konstytucyjną na wzór XVII-wiecznej Anglii, lecz przypominałaby raczej sytuację w ówczesnej Polsce z niczym nieograniczoną władzą szlachty. To zaś, podobnie jak stało się to w polskich warunkach, doprowadziłoby do rozpadu państwa, oderwania części ziem, a może nawet rozbioru Królestwa Czeskiego między sąsiadów. Monarchia stanowa rządzona przez szlachtę, nawet czeską (w rozumieniu terytorialnym, nie etnicznym), nie stanowiła sama w sobie gwarancji pozytywnego rozwoju sytuacji w państwie.

Konsekwencje bitwy pod Białą Górą i pokoju westfalskiego dla czeskiej kultury da się ocenić o wiele łatwiej. Brak możliwości powrotu protestanckich elit do kraju odbił się negatywnie na rozwoju kulturalnym ziem czeskich. Tak postrzegał to m.in. uczeń Pekařa, Zdeněk Kalista ${ }^{32}$. Jednak i tu nie należy sprawy demonizować, bowiem i wśród katolików nie brakło mądrych i wykształconych ludzi, którzy z biegiem czasu zdołali, choć częściowo, zastapić dawne elity.

(ttumaczyl z czeskiego Marcin Czyżniewski)

\section{Bibliografia}

Dokumenty publikowane:

Tekst artykułów konfederackich, Veselý Z., Dějiny českého státu v dokumentech, Praha 2003, s. 152-170.

Monografie:

Bílek T. V., Dějiny konfiskací v Čechách po roce 1618, I, Praha 1882; II, Praha 1883.

Čechura J., Zimni král aneb české dobrodružství Fridricha Falckého, Praha 2004.

${ }^{32}$ Z. Kalista, Stručné dějiny československé, 2. vyd., Praha 1992, s. 232. 
Janáček J., Valdštejn a jeho doba, 2. vyd., Praha 2003.

Kadlec J., Přehled českých církevních dějin, II, Řím (Roma)-Praha, 1987.

Kalista Z., Stručné dějiny československé, 2. vyd., Praha 1992.

Kilián J., 11. 12. 1617 - Uzavření kostela v Hrobu. Na cestě k defenestraci, Praha 2007.

Koldinsk á M., Kryštof Harant z Polžic a Bezdružic, Praha-Litomyšl, 2004

Kollman J., Valdštejnův konec. Historie druhého generalátu, Praha 2001.

Palacký F., Dějiny národu českého v Čechách a v Moravě dle původnich pramenův, I, 5. vyd., Praha 1933.

Pekař J., Bílá Hora, [w:] O smyslu českých dějin, 3. vyd., Praha 1990.

Pekař K., Dějiny valdštejnského spiknutí, 3. vyd., Praha 2008.

Petráň J., Staroměstská exekuce, 4. wyd., Praha 2004.

Pěkný T., Historie Židů v Čechách a na Moravě, Praha 1993.

Polišenský J., Anglie a Bílá Hora 1618-1620, Praha 1949.

Polišenský J., Nizozemská politika a Bílá Hora, Praha 1958.

Rychlík J.-Penčev V., Od minulosti k dnešku. Dějiny českých zemí, Praha 2013.

Biografie:

Bílek T. V., Dějiny konfiskací v Čechách po roce 1618, I, Praha 1882; II, Praha 1883.

Fukala R., Jan Jiři Krnovský. Stavovské povstání a zápas s Habsburky, České Budějovice 2005.

Polišenský J.-Kollman J., Valdštejn. Ani císař, ani král, 2. vyd., Praha 2001.

Artykuły:

Rychlík J., Bitva na Bílé Hoře a mýtus o třistaleté porobě, [w:] Literárni mystifikace, etnické mýty a jejich úloha při formování národního vědomí. Studie Slováckého muzea, 6, 2001.

Schwarz K. W., Der ,politische” Kalvinist Georg Erasmus Tschernembl (1567-1626) und sein Kampf um die Religionsfreiheit in Oberösterreich, [w:] Historia Ecclesiastica, I, 2010, No 1.

Jan Rychlik, prof. Ur. 26 listopada 1954 r. w Pradze. W 1979 r. ukończył studia z zakresu historii i etnologii na praskim Uniwersytecie Karola; w 1985 r. uzyskał doktorat w Zakładzie Folklorystyki Bułgarskiej Akademii Nauk, zaś w 1998 r. doktorat z historii w Zakładzie Historii Akademii Nauk Republiki Czeskiej. Jest profesorem nowoczesnej historii Czech i Słowacji w Zakładzie Historii Czech Wydziału Filozoficznego Uniwersytetu Karola w Pradze i pracownikiem naukowym Instytutu Masaryka i Archiwum Akademii Nauk Republiki Czeskiej. Doktor honorowy Uniwersytetu im. św. Klimenta Ohridskiego w Sofii. Zajmuje się historią Czech, Słowacji i krajów bałkańskich. 